\title{
Institutional Entrepreneurship and Change in Fields ${ }^{1}$
}

\author{
Cynthia Hardy \\ Department of Management \& Marketing \\ University of Melbourne \\ Parkville \\ Victoria, 3010 \\ Australia \\ Email: chardy@unimelb.edu.au \\ Tel: +61-3-8344-3719 \\ Fax : +61-3-83443731 \\ $\&$ \\ Steve Maguire \\ Desautels Faculty of Management \\ McGill University \\ 1001 Sherbrooke Street West \\ Montreal, H3A 1G5 \\ Canada \\ Email: steve.maguire@mcgill.ca \\ Tel: 1-514-398-2115 \\ Fax: 1-514-398-3876

\section{Forthcoming in} \\ Handbook of Organizational Institutionalism (second edition)
}

Revised February 2016

\footnotetext{
${ }^{1}$ The authors gratefully acknowledge the financial support of the Social Sciences and Humanities Research Council of Canada (435-2014-0256) and the Australian Research Council (Discovery funding scheme, project number DP110101764).
} 


\section{Introduction}

The term 'institutional entrepreneurship' refers to the "activities of actors who have an interest in particular institutional arrangements and who leverage resources to create new institutions or to transform existing ones" (Maguire, Hardy \& Lawrence, 2004: 657); while institutional entrepreneurs are those actors to whom the responsibility for new or changed institutions is attributed. These concepts are most closely associated with DiMaggio's (1988: 14) work in which he argued that "new institutions arise when organized actors with sufficient resources (institutional entrepreneurs) see in them an opportunity to realize interests that they value highly". Institutional entrepreneurs are therefore typically associated with change in fields in the form of new institutions or radical changes in existing ones, although institutional entrepreneurs can also work to maintain or to disrupt and dismantle institutions (Lawrence \& Suddaby, 2006). Some studies indicate that individual institutional entrepreneurs play highly influential, if not determining, roles in bringing about institutional change. Other writers, however, are more cautious of attributing too much agency to specific actors and have, instead, emphasized the collective, incremental and multi-level effects of institutional entrepreneurship on institutional fields, including its unintended consequences.

Underpinning much of the interest in institutional entrepreneurship is the paradox of embedded agency (DiMaggio \& Powell, 1991; Seo \& Creed, 2002).

The theoretical puzzle is as follows: if actors are embedded in an institutional field ... how are they able to envision new practices and then subsequently get others to adopt them? Dominant actors in a given field may have the power to force change but often lack the motivation; while peripheral players may have the incentive to create and champion new practices, but often lack the power to 
change institutions (Garud, Hardy \& Maguire, 2007: 961).

The concept of embedded agency raises an interesting question for institutional theorists: how do actors envision and champion institutional change if they are embedded in an institutional field and subject to its regulative, normative and cognitive pressures? As Maguire (2007: 674) points out, "actors who are truly embedded" are not supposed to imagine, desire or realize alternative ways of doing things "because institutionalized arrangements and practices structure cognitions, define interests and, in the limit, produce actors' identities". So, dominant actors seem less likely to come up with particularly novel ideas or to be motivated by the idea of change - they often fail to see beyond "prevailing 'recipes", they are "exposed to normative processes", and their interests are "aligned with current practices" (Greenwood \& Suddaby, 2006: 29). Conversely, peripheral actors in a field, who are less embedded, are less privileged by existing institutional arrangements, and therefore have more to gain from change. Less constrained by dominant practices, they may also be more innovative and have more ideas as to what change might look like (e.g., Leblebici et al., 1991). However, these actors are unlikely to have the power and resources necessary to realize change, especially if it means convincing or coercing other members in the field - including dominant players - to alter their practices (Maguire, 2007). So, dominant central actors have the means to drive institutional change, but lack the motivation and the vision to be institutional entrepreneurs; while peripheral actors have both motivation and vision, but lack the resources and networks to bring about field level change.

Work on institutional entrepreneurship has developed as scholars have explored this paradox, seeking to understand how actors in a field bring about institutional change. In this chapter, we review this body of research. ${ }^{2}$ We start by examining the types of actor that are most

\footnotetext{
${ }^{2}$ In order to focus on this body of work, we have had to omit discussion of related topics such as institutional logics. We refer readers to the dedicated chapter on logics in this Handbook.
} 
likely to take on the role of institutional entrepreneur, by reviewing research that explores the attributes of institutional entrepreneurs, as well as the place they occupy in the field they are trying to change. The second section describes the field conditions that help to initiate institutional entrepreneurship - how particular aspects of an institutional field provide a context in which ideas for change are more likely to emerge and take hold. In the third section we consider the role of interpretive struggles and examine how contests over meaning are associated with processes of institutional entrepreneurship. In the fourth section, we discuss intervention strategies - patterned action by institutional entrepreneurs as they seek to change a field. In reviewing this literature, we reflect on the actor-centric and process-centric accounts of institutional entrepreneurship noted in our chapter in the first edition of this Handbook (Hardy \& Maguire, 2008). We argue that, in many respects, much of the more recent work has taken the institutional entrepreneurship process seriously. Nonetheless, and somewhat ironically, this has led to the continuation of portrayals of 'heroic' actors. We suggest that future research might provide greater insight from a more reflexive, critical orientation of institutional entrepreneurship.

\section{Institutional Entrepreneurs}

Who can become an institutional entrepreneur? Who are the actors who "break away from scripted patterns of behaviour" (Dorado, 2005: 388) and strive "to develop strategies and shape institutions" (Leca \& Naccache, 2006: 627). At a basic level, researchers have examined different types of actors that initiate institutional change and act as institutional entrepreneurs, including individuals (Fligstein, 2001b; Lawrence \& Phillips 2004; Maguire et al., 2004; Dew, 2006; Tracey, Phillips, \& Jarvis, 2011; Wright \& Zammuto, 2013), organizations (e.g., Garud et al., 2002; Hensman, 2003; David, Sine \& Haveman, 2013), various levels of government and 
their agencies (Montiel \& Husted, 2009; Nasra \& Dacin, 2010; Stål, 2011; Buhr, 2012;

Covaleski, Dirsmith \& Weiss, 2013), and other forms of social groups and communities, including networks, associations, and social movements (Lounsbury et al., 2003; Demil \& Bensédrine, 2005; Dorado, 2005; Rao et al., 2000; Dorado, 2014).

Researchers have, however, explored more complex questions than whether individuals, organizations or collectives can act as institutional entrepreneurs. Accordingly, we examine work that has linked institutional entrepreneurship to properties associated with particular types of actor, as well as to the specific positions that actors occupy in a given field.

\section{Properties}

One approach to understanding who initiates institutional change focuses explicitly on the properties - special characteristics, qualities and abilities - that distinguish institutional entrepreneurs from others in the field and which allow them to envision and promote alternative arrangements (e.g., Henfridsson \& Yoo, 2014). Lepoutre and Valente (2012) argue that 'institutional nonconformity' is only possible when organizations possess cognitive/symbolic and material immunity to dominant institutional logics. Such work sees the institutional entrepreneur as an "analytically distinguished social type who has the capability to take a reflective position towards institutionalized practices and can envision alternative modes of getting things done" (Beckert, 1999: 786, emphasis in original). At the level of the individual, the notion of an institutional entrepreneur thus opens up avenues of research informed by cognitive psychology and "the development of systematic tools for predicting how individual cognition is translated into actions in the institutional environment" (George, Chattopadhyay, Sitkin \& Barden, 2006: 348). Similarly, avenues of research informed by psychodynamic approaches to individuals are also opened up. For example, Kisfalvi and Maguire (2011) identify 
the psychosocial influences on one institutional entrepreneur - Rachel Carson - and argue that events in her life influenced her cognitive and emotional make up, which in turn shaped the meanings she attached to institutionalized practices and, hence, her entrepreneurial activities.

Other work has examined the characteristics of institutional entrepreneurs using a critical realist perspective (Mutch, Delbridge \& Ventresca, 2006; Leca \& Naccache, 2006). For example, Mutch (2007) uses Archer's (2003) work to study Sir Andrew Barclay Walker, who pioneered the practice of directly managed public houses in England. Mutch (2007) suggests that Walker was an able to act as an institutional entrepreneur because of his reflexivity. Specifically, he was an "autonomous reflexive" - an actor who reflected in relative isolation from the concerns of others, as a result of which he was more likely to experience conflict with the structures that surrounded him and, therefore, to seek opportunities for change. Leca \& Naccache (2006) use critical realism to explore the activities of an organization, rather than an individual - ARESE, the first company to act as a social rating agency in France. These authors show how, despite being embedded, reflexivity allowed this organization to contribute to the institutionalization of socially responsible investment in that country

Work in the critical realist tradition, while focusing on the institutional entrepreneur, also places considerable emphasis on the institutional context, reminding us that actors are products of the institutional fields in which they operate. Actors and their interests, goals and strategies are institutionally, culturally and historically shaped (Clemens \& Cook, 1999; Meyer, 2006). Which actors have "the right to have interests, what interests are regarded as reasonable or appropriate, and what means can be used to pursue them are all products of socially constructed rules", such that "who has the right to take self-determined and self-interested actions - is expected to vary over time and place" (Scott, 1995: 140). In order to recognize this mutually 
constitutive nature of actors and fields, research has focused more directly on the actor's position in the field as we discuss in the next section.

\section{Positions}

To emphasize that the institutional entrepreneur is as much a product of the field as its architect, researchers have investigated the way in which fields create a limited number of subject positions (Maguire et al., 2001) or social positions (Battilana, 2006) i.e., those legitimated identities available in a field from which actors can take action (Bourdieu, 1990). Institutional fields are "structured systems of social positions within which struggles or maneuvers take place over resources, stakes and access" (Oakes et al., 1998: 260). Power relations - including the capital or resources available to different actors, as well as a sense of the social 'game' being played, or what Bourdieu calls "habitus" (see Everett, 2002) - are thus embedded in the field rather than 'owned' or 'possessed' by individual actors. The actor's position in the field provides the individuals or organizations located in that position with institutionally defined interests and opportunities (Bourdieu \& Wacquant, 1992) and, in some cases, the opportunity to exert power over the field at a particular point in time (Bourdieu, 1986). According to this view, institutional entrepreneurs do not 'have' power; instead, they occupy (or fail to occupy) subject positions that allow them to exercise power in - and on - a particular field. For example, Maguire et al. (2004), in their study of the emerging field of HIV/AIDS advocacy in Canada, found that institutional entrepreneurs were actors who occupied subject positions that provided them with legitimacy with respect to diverse stakeholders, enabling them to bridge stakeholders in ways which facilitated access to dispersed resources.

Empirical studies have found that, despite the paradox of embedded agency, powerful actors located in dominant positions in mature fields do sometimes initiate institutional change. 
For example, the provincial government in Alberta, Canada, imposed business-planning practices on government departments by fiat (Townley, 2002). Similarly, it was the largest accounting firms that promoted the adoption of the multi-divisional form in the Canadian accounting field (Greenwood et al., 2002; Greenwood \& Suddaby, 2006). In the field of French cuisine, change in the form of nouvelle cuisine came from chefs "in the centre of the French culinary world who had received honors from the French state and had garnered plaudits from the Guide Michelin" (Rao et al., 2003: 804).

Such research has shown that central actors may not be as embedded in a single field as strong institutionalist views would suggest. Those who act as institutional entrepreneurs may have access to alternative practices in other fields through a variety of mechanisms. For example, many leading French chefs visited Japan and obtained new ideas from a completely different culinary field to develop nouvelle cuisine (Rao et al., 2003). Large Danish organizations introduced American practices of diversity management as a result of employees and consultants who had experience of other fields, including overseas work and involvement in the feminist movement (Boxenbaum \& Battilana, 2005). Research has also shown that the large, elite accounting firms that introduced the multi-divisional form into the field of Canadian accounting were not as embedded as might have been thought, given their central location in a highly institutionalized mature field. Greenwood \& Suddaby (2006: 40) found that these firms bridged a number of organizational fields, including those of their global clients. This 'boundary bridging' exposed actors to alternative practices, while their scope and size insulated them from regulatory pressures and their reliance on in-house training reduced their exposure to normative influences, both of which might have prevented change (although, ultimately, the change was unsuccessful). 
Research has also shown how less dominant, peripheral actors can initiate institutional change. These actors are attracting increasing research attention, as a result of both a backlash against the obsession with individual 'heroic' institutional entrepreneurs (e.g., Levy \& Sculley, 2007), as well as the growing interest in practice-driven institutional change (Smets, Morris \& Greenwood, 2012). For example, despite the fierce defense of traditional distribution networks in the American music industry, "disruptive challengers" like Napster were able to undermine "status quo incumbents" and open up space for new practices (Hensman, 2003). Fringe players initiated change in the US broadcasting industry by introducing new practices that were adopted by dominant players and became conventions in the field (Leblebici et al, 1991). Activist organizations, such as environmental NGOs, have played an important role in the institutionalization of recycling practices (Lounsbury et al., 2003). Consumers have catalyzed institutional change in the form of text messaging (Ansari \& Phillips, 2011). Institutional entrepreneurship can also be initiated from outside the field as in the case of Rachel Carson, whose work led to changes in institutionalized practices of pesticide use (Maguire \& Hardy, 2009; Kisfalvi \& Maguire, 2011). Similarly, David, Sine \& Haveman (2013) show how actors located outside of the field were able to leverage non-traditional resources to establish the nascent field of management consulting. New actors in a field can also initiate change (Sauder, 2008).

Peripheral and external actors are expected to find it easier to develop ideas for change because they are less embedded in the field - less aware of institutional norms and prescriptions and more likely to be exposed to alternative ideas outside the field (Greenwood \& Suddaby, 2006; Maguire, 2007). They are also likely to be motivated to bring about change since they are often disadvantaged by prevailing arrangements (Leblebici et al., 1991). The paradox in this 
situation is less about how such actors come up with ideas for institutional change but, rather, how they get other field members to adopt them, as we discuss in more detail in the section on intervention strategies below.

In sum, individuals and various types of organizations can act as institutional entrepreneurs. Some research emphasizes institutional entrepreneurs' unique abilities and features that, in effect, make them a privileged "species" of actor - one "increasingly endorsed with specific qualities 'normal' actors do not possess" (Meyer, 2006: 732). Other studies seek to explain who becomes an institutional entrepreneur with reference to the position they occupy in a field. The latter approach, which seeks to establish an institutional grounding of the institutional entrepreneur, appears to be more robust insofar as it recognizes that the 'exceptional' ability of institutional entrepreneurs to see or create 'a window of opportunity' needs to be considered in relation to the way in which the field produces their interests, skills, and stocks of knowledge (Meyer, 2006), as we explore in the next section.

\section{Initiating Field Conditions}

Another line of enquiry concerned with resolving the paradox of embedded agency has tried to identify particular field conditions that create opportunities for institutional entrepreneurship. We begin this section by summarizing work that explores how particular stimuli may trigger institutional entrepreneurship. We then discuss how the state of a particular field can also facilitate institutional entrepreneurship.

\section{Stimuli}

Some research, especially work that adopts an economic approach to institution building and views actors as rational, argues that uncertainty in a field prompts institutional change as actors seek to reduce it. Generally speaking, uncertainty is "the degree to which future states of 
the world cannot be anticipated and accurately predicted" (Pfeffer \& Salancik, 1978: 67). In economics, it refers to situations where actors cannot define rational strategies because they cannot calculate probabilities for decision outcomes (Beckert, 1999). According to this view, institutions, because they structure and make predictable actors' behaviour, are solutions to the problems faced by cognitively limited actors whose interdependence with other actors creates the possibility of opportunistic behaviour and increased transaction costs (Coase, 1937; North, 1990). Working in this tradition, Dew (2006: 16) elaborates the concept of Coasian-style institutional entrepreneurship as "the activity of initiating, creating and leading organizations that specialize in developing institutional frameworks that lower transaction costs" for other actors in the field. He offers the example of a grocery executive who pioneered the now widespread and institutionalized technology standards and associated practices for using bar codes and universal product codes, to facilitate exchange relationships.

In this way, institutional entrepreneurship is associated with identifying and solving problems in a field. For example, adverse performance of the major accounting firms in Canada called into question the efficiency of the traditional organizational form in the field, prompting some to adopt a new multi-divisional form (Greenwood \& Suddaby, 2006). Similarly, the inflexibility of the Association to Advance Collegiate Schools of Business (AACSB) model of business education in light of increasingly diverse student demands and business school mandates created "ambiguity, scarcity in legitimizing resources ... [and] selection pressures" which, in turn, led to moves to expand the field to include European business schools (Durand \& McGuire, 2005: 184). The rise of socially responsible investing in France created the problem of how to measure corporate social performance, as a result of which institutional entrepreneurs sought to institutionalize standardized measures (Dejean, Gond \& Leca, 2004). The problem of 
heart disease in Finland has led to new institutions aimed at changing grass-root understandings of the relationship between food, other lifestyle factors, and heart health (Ritvala \& Granqvist, 2009). Once some actors adopt new practices, evidence of their effectiveness, such as positive market feedback or improved social welfare outcomes, increases their legitimacy among other actors and encourages their wider diffusion and adoption (e.g., Lee \& Pennings, 2002).

According to such work, institutional entrepreneurs bring about change as they try to solve problems and reduce uncertainty. One would therefore expect to see acts of institutional entrepreneurship correlated with field-level problems or a high degree of field-level uncertainty. Interestingly, Beckert (1999: 783) argues the opposite: "strategic agency that violates existing institutional rules can be expected in situations characterized by relatively high degrees of certainty within an institutional field." He argues that this is because actors, if rational, need to be able to assign probabilities to the possible consequences of their choices and to work out whether change is going to be profitable or beneficial before taking action. Consequently, he suggests that uncertainty follows the 'creative destruction' of the institutional order associated with institutional entrepreneurship, rather than precedes it. The exact nature of the relationship between uncertainty and institutional entrepreneurship is, therefore, not entirely clear, and further research is warranted.

Another body of work has focused on the tensions and contradictions that are present in fields, even mature ones. A range of writers have noted that, despite work that sees institutional fields as totalizing and shared phenomena, they are in fact riven with inconsistencies and conflict (Seo \& Creed 2002; Zilber, 2002; Rao et al., 2003; Dorado, 2005; Creed, DeJordy \& Lok, 2010). So, although institutional processes may appear to be stable because differences among actors are "temporarily resolved by socially negotiated consensus," this appearance of stability is 
"misleading" (Greenwood et al., 2002: 59). Institutions are not homogenous or complete. Nor do they precisely determine behaviour. Instead, multiple institutions may exist in a given field and conflict with each other, new members with different histories and experiences may join a field, and existing members may have access to more than one field and therefore exposure to a range of practices (Clemens \& Cook, 1999). Institutional change thus results as human praxis is brought to bear on these tensions and contradictions. Individuals use them to reflect on and critique the limits of present institutional arrangements and to inspire ideas for new ones, leading them to mobilize and engage other actors in collective action intended to reconstruct the field (Seo \& Creed, 2002).

\section{States}

Another body of work has focused on how the particular state of the field is associated with greater likelihood of institutional entrepreneurship (e.g., Dorado \& Ventresca, 2013). Consistent with the work on contradictions, which allow actors to reflect on existing institutional arrangements, and the work on uncertainty or problems, which provide actors with a motivation for institutional change, it has been argued that fields in a state of crisis may be particularly conducive to institutional entrepreneurship. A crisis can surface contradictions and tensions in even highly structured, mature fields and give rise to problems that require solutions (Fligstein \& Mara-Drita, 1996). Accordingly, 'disruptive events' (Hoffman, 1999), 'shocks' (Fligstein, 1991), 'triggering events' (Rao et al., 2003) and 'jolts' (Meyer, 1982) - which can take the form of social upheaval, technological disruptions, regulatory change, or the publication of books, reports, and media stories (e.g., Davis, Diekmann, \& Tinsley, 1994; Garud, Jain, \& Kumaraswamy, 2002; Lounsbury, 2002; Maguire \& Hardy, 2009) - in generating some form of crisis are conducive to institutional entrepreneurship. 
Fligstein (2001a) shows how a crisis in the European Union enabled the European Commission to act as an institutional entrepreneur and develop the Single Market Program. Disruptive events are capable of "ending what has become locked in by institutional inertia" through the way they create "disruptive uncertainty for individual organizations, forcing the initiation of unorthodox experiments that diverge from established practice" and "throwing entire industries into the throes of quantum change" (Hoffman, 1999: 353). Such events may precipitate the entry of new players into an organizational field, facilitate the ascendance of existing actors, or change the intellectual climate of ideas, making it easier to disrupt existing practices and raise awareness of possible new ones, (Greenwood et al., 2002; Greenwood \& Suddaby, 2006).

It has also been argued that emerging fields offer considerable scope for institutional entrepreneurship (Maguire, et al, 2004; also see Purdy \& Gray, 2009). Child, Lu and Tsai (2007) show how the state took advantage of the emergent nature of China's environmental protection field to act as an institutional entrepreneur, drawing on developments in other fields related to international environmental concerns and domestic economic reform. Nasra and Dacin (2010), in examining the role of the state as institutional entrepreneur in the Middle East, show how the emergence of Dubai's unique institutional environment and political economy from the beginning of the nineteenth century until present day provided opportunities for Dubai's rulers to act as institutional entrepreneurs. Avetisyan and Ferrary (2013) focus on the role of rating agencies as institutional entrepreneurs in the emerging field of corporate social responsibility, noting differences between France and the US. What these studies collectively indicate is that the constraints in emerging fields are fewer compared to mature fields since there are fewer established patterns to mimic and power is more diffuse. This lack of institutionalized practices 
and clearly identifiable norms, combined with fluid relationships and conflicting values, makes it easier for actors to bring about institutional change, as well as affording them considerable advantage as they shape the field.

A new development concerning the state of the field and institutional entrepreneurship is the work on 'field-configuring events', which are "temporary social organizations ... in which people from diverse organizations and with diverse purposes assemble periodically, or on a onetime basis" (Lampel \& Meyer, 2008: 1026). This work focuses on particular events that bring members of the field together at certain points, changing the state of the field temporarily, i.e. for a delimited period of time. Field-configuring events generate new, interconnected 'discursive spaces' that are not normally available to members of the field, and in which the normal understandings and rules in the field regarding appropriate forms of text production, distribution and consumption are suspended or modified. In addition, the co-location of actors means that texts flow more readily between discursive spaces than they normally do (Hardy \& Maguire, 2010). In this way, field-configuring events provide a temporary setting in which there is more scope for institutional entrepreneurship and change, although Schüssler, Rüling and Wittneben's (2014) examination of discursive spaces in the United Nations' climate change negotiations shows that field-level maintenance, rather than change, can also be the outcome.

In sum, certain stimuli - uncertainty, problems, tensions and contradictions in a field can establish favorable initiating conditions for institutional entrepreneurship by motivating and furnishing ideas for change. Additionally, fields in particular states, especially mature fields in crisis following a disruptive event, emerging fields, and fields in which field-configuring events are staged, appear more likely to present opportunities for institutional entrepreneurship. Much of this work tends to conceptualize the state of the field as a set of objective conditions that 
triggers (or fails to trigger) institutional entrepreneurship. Munir (2005), however, reminds us that the way in which events and contexts are interpreted and given meaning is an important part of institutional entrepreneurship. In other words, for an event to be deemed disruptive - creating a situation of uncertainty, contradiction or tension, causing a crisis, or representing a temporary hiatus in institutionalized rules - requires that actors interpret it as such. The role of interpretation in institutional entrepreneurship is discussed in more detail in the following section.

\section{Interpretive Struggles}

The paradox of embedded agency recognizes that some form of struggle is likely between field members when some want change and others do not. As a result, researchers have delved into the complex, ongoing interpretive struggles over meaning that accompany institutional entrepreneurship activities, the outcomes of which are not necessarily predictable or controllable (Covaleski et al., 2013). Emphasizing translation at the micro-level (Zilber, 2002) and discourse at the macro-level (Phillips et al., 2004; Schmidt, 2008, 2010), this work builds on the idea that institutions are formed as meanings come to be shared and taken for granted. In contrast to the diffusion metaphor that has dominated much of institutional theory, and which "connotes a transmission of a given entity," the translation metaphor "connotes an interaction that involves negotiation between various parties, and the reshaping of what is finally being transmitted" (Zilber, 2006: 283). Field members are not carriers of predetermined institutional meanings, diffusing them intact and unchanged throughout a field; rather, they are active narrators and interpreters of accounts of practices whose meanings are negotiated in ongoing, complex processes (Sahlin \& Wedlin, 2008; Maguire \& Hardy, 2009; Hardy \& Maguire, 2010). 
Individuals' interpretations can thus be seen "as part of institutional agency - the social actions that create, reproduce, and change institutions" (Zilber, 2002: 236). Institutional entrepreneurs are also "institutional interpreters, that translate and communicate institutional pressures" (Rothenberg \& Levy, 2012: 34) by drawing on different discourses and finding new ways to frame and theorize change. From this perspective, institutional entrepreneurship is seen to emerge from novel interpretations and struggles over meaning, such as the struggle between neo-liberalist entreaties on the part of the Governor of Wisconsin in trying to transform the State's welfare system and the appeals to fairness and poverty-reduction on the part of opponents (Covaleski et al., 2013). Meaning thus takes on multiple roles in an institutional field. First, it is the outcome for which actors struggle. Different actors have stakes in particular meanings and attempt to assert their preferred ones (Grant \& Hardy, 2004). Second, meanings are the medium through and within which power struggles take place as actors try to influence institutional change (Zilber, 2006). In this regard, meanings are a resource (Zilber, 2002) - actors draw on them to support their positions and to undermine those of opponents. Third, meanings are a constraint, since field and societal level logics (Thornton \& Ocasio, 2008), myths (Zilber, 2006) and discourses (Phillips et al., 2004) are not infinitely pliable.

Drawing on these ideas, a growing body of work has explored the processes of discursive struggle through which institutional entrepreneurship succeeds or fails. Zilber (2002: 251) shows how struggle over the meaning of institutionalized practices at a rape crisis centre - whether they were 'feminist' or 'therapeutic' - affected power relations inside the organization and, as a result, the services that it provided, although not in predictable, predetermined or clearly managed ways. Maguire \& Hardy (2006) examine the creation of the Stockholm Convention on Persistent Organic Pollutants, which is a new global regulatory institution that, consistent with 
the discourse of 'precaution', bans toxic chemicals based on uncertain scientific knowledge of the risks they pose. The new institution was the outcome of discursive struggle among actors over the meaning of precaution: some actors promoted the new discourse of precaution, while others countered with the legacy regulatory discourse of 'sound science'. As a result, actors on both sides were forced to engage with and reconcile competing discourses. It was out of this struggle that the particular institution emerged.

In another study, Zilber (2007) shows how institutional entrepreneurship in the high-tech industry in Israel following the 2000 dot.com crash involved the construction of a shared story of the crisis that reinforced the established institutional order. Yet, at the same time, actors were also telling separate 'counter-stories' that called for changes in the institutional order. Actors used stories both to protect vested interests in the current institutional order, as well as to agitate for change - all at the same time. Maguire and Hardy (2009) show how complex processes of producing, distributing and consuming texts led to the deinstitutionalization of practices of using the pesticide DDT in the US between 1962 and 1972. In this case, institutional entrepreneur Rachel Carson (1962) problematized the use of chemical pesticides including DDT with her book Silent Spring. However, the eventual outcome emerged from a struggle involving countless scientific, legal, regulatory, government and public texts - and counter-texts - during which meanings were translated, and even subverted, in ways never intended by Carson.

As these examples illustrate, this body of work emphasizes the complex and contradictory processes through which meaning is negotiated and stabilized. It highlights not only the potential 'messiness' of institutional entrepreneurship processes as discursive maneuvers are met with counter-moves, but also the potential for outcomes that are not necessarily those originally intended by the actors involved. It stands in contrast to the bulk of 
work on institutional entrepreneurship, which seeks to explain the effectiveness or success of institutional entrepreneurs in bringing about intended institutional change, usually with reference to specific strategies for intervening in a field, as we discuss in the next section.

\section{Intervention Strategies}

Institutional entrepreneurship requires actors to dislodge existing practices (in the case of mature fields), introduce new ones, and then ensure that they become widely adopted and taken for granted by other actors in the field. How do institutional entrepreneurs, whether they are central or peripheral players, succeed in their struggles to change institutional fields? This question occupies a large portion of the literature, which focuses on identifying and explicating the strategic interventions made by institutional entrepreneurs to bring about change. We synthesize this diverse work in terms of three broad themes: the mobilization of resources, the construction of rationales for institutional change, and the forging of new inter-actor relations to bring about collective action. Collectively, this work suggests that if institutional entrepreneurs are to bring about institutional change, they must mobilize and recombine materials, symbols and people in novel and even artful ways (see Misangyi, Weaver \& Elms, 2008; Aldrich, 2012).

\section{Resources}

Resource mobilization has been central to the notion of institutional entrepreneurship since DiMaggio's (1988: 14) definition highlighted the necessity of "sufficient resources" to create or change institutions. Despite this centrality, research is often vague as to what is meant by the term 'resources' as well as what is done with them. Certainly, a wide range of resources have been mentioned in the literature, including political, financial and organizational resources (Beckert, 1999; Greenwood \& Suddaby, 2006), material resources (Lawrence \& Suddaby, 2006; Monteiro \& Nicolini, 2014, cultural resources (Creed, Scully \& Austin, 2002; David et al., 2013), 
affiliations and networks (Montiel \& Husted, 2009; Ritvala \& Granqvist, 2009; Raffaelli \& Glynn, 2014), and discursive resources (Hardy \& Phillips, 1999; Hensman, 2003; Lawrence \& Phillips, 2004; Maguire \& Hardy, 2006), including scientific knowledge (Ritvala \& Granqvist, 2009), and history (McGaughey, 2013). In this section, we focus on material resources, ${ }^{3}$ which, research suggests, are mobilized by institutional entrepreneurs as a lever against other actors subsidiary actors, allies, and external constituencies - to negotiate support for the change project in question (DiMaggio, 1988). In some instances, powerful actors may control sufficient resources to impose change on an institutional field by themselves (Dorado, 2005), but it appears that, most of the time, institutional entrepreneurship involves a degree of dependency on other actors and their resources to make bargaining and negotiating inevitable. This view is consistent with Colomy's (1998) claim that institutional entrepreneurs employ strategies that operate through exchange mechanisms: support for a project is contingent on the perception that tangible and/or intangible benefits are forthcoming to other actors. Some entrepreneurial strategies are premised on positive inducements offered to prospective allies in exchange for their support. Others are premised on negative inducements in the form of threats to establish a bargaining relationship in which the coerced party's "best hope is that it will be no worse off than it would have been had the coercive relationship never commenced" (Turner \& Killian, 1987: 298-299; quoted in Colomy, 1998: 280). In this way, institutional entrepreneurship involves materially rewarding supporters and punishing opponents.

\footnotetext{
${ }^{3}$ As can be seen from this heterogeneous list, the notion of resource mobilization can include material, symbolic and human/organizational resources. However, because of important differences among them, particularly how they relate to power, we address them separately in terms of three themes - resources, rationales, and relations. Broadly speaking, these themes correspond to the three interlaced dimensions of field structure - material, discursive, and organizational - proposed by Levy and Scully (2007). At the same time, we acknowledge the overlap. For example, as David and colleagues (2013) show in the case of the emerging field of management consulting, resources can take the form of cultural capital and become intertwined with the creation of rationales (also see Misangyi et al., 2008).
} 
If institutional entrepreneurs do not control rewards and punishments, they can recruit allies that do. Several studies draw attention to how institutional change in a given field depends upon other extant institutions, especially legal and professional ones in which institutions to be changed are nested (cf. Holm, 1995). In other words, the formal authority of other actors such as the state and professional associations can be harnessed as a resource to support change. For example, in his study of the early stages of the emergence of the automobile industry, Rao (2002) demonstrates how one mechanism for generating constitutive legitimacy for innovative products around which new industries emerge is the enactment of laws that make the product legal and specify how it can be made, sold, used, etc., thus authorizing and codifying understandings of the new artifact and practices of using it. Similarly, Garud et al. (2002) note how the legal system can be drawn upon to create new rules or to enforce old ones, both of which can be used to advance institutionalization projects. Of course, opponents of institutionalization projects can also seek to enroll higher authorities, and different authorities may clash. So, while Greenwood et al. (2002) show how professional associations lent their authority to the elite accounting firms' adoption of a new multidivisional organizational form, they also note the ultimately determining role played by the state in legislating an end to experimentation with this form.

\section{Rationales}

Institutional entrepreneurship also involves interventions in the discursive or ideational realm as actors construct and communicate rationales or reasons to other actors concerning why they should support or, at a minimum not resist, the institutionalization project in question. Institutional entrepreneurs therefore construct entrepreneurial (Colomy, 1998) or legitimating accounts (Creed et al., 2002) of their projects. In so doing, they may 'theorize' institutional change by specifying problems associated with existing practices and justifying new ones as a 
solution (Greenwood et al., 2002; Monteiro \& Nicolini, 2015); tell stories or narratives (Zilber, 2007; Hardy \& Maguire, 2010); and deploy rhetoric strategically (Harmon, Green \& Goodnight, 2015) - although sometimes unsuccessfully (Suddaby \& Greenwood, 2005; McGaughey, 2013). An array of arguments may be developed for different constituencies, providing each with a different rationale for participating in the institutional project (Maguire et al., 2004); and it is through the production, distribution and consumption of texts (Philips et al., 2004) that ideas and arguments are shared (Boxenbaum \& Battilana, 2005).

Institutional entrepreneurs thus frame desired changes in ways that will generate collective action (Benford \& Snow, 2000; Garud et al., 2002; Lounsbury et al., 2003). A collective action frame is a coherent interpretive structure that accomplishes three tasks: punctuation, which identifies a problem and defines it as important; elaboration, which includes a diagnosis of the problem describing who or what is responsible for it, as well as a prognosis describing what is required to correct it; and motivation, which encourages actors to participate in change (Creed et al., 2002; Misangyi, Weaver \& Elms, 2008). By using particular frames, institutional entrepreneurs can increase the chances of successful institutional change as collective interpretations evolve and amplify to become institutionalized and shape subsequent interpretations (Gray, Purkey \& Ansari, 2015). In framing and offering rationales for their projects, the validity of claims "is rarely demonstrated in an unequivocal way, however, and rests chiefly on the project's perceived conformity to institutional myths" (Colomy, 1998: 289). As a result, institutional entrepreneurs often draw on existing field-level logics (Seo \& Creed, 2002) and dominant discourses (Hardy \& Phillips, 1999; Lawrence \& Phillips, 2004) to position their projects in terms of existing categories and schema (Hargadon \& Douglas, 2001) in order to make change comprehensible and meaningful to other actors. For example, Tracey and 
colleagues (2011) show how institutional entrepreneurs reframed solutions to the problem of homelessness by combining two different institutional logics (for-profit and non-profit) that had previously appeared contradictory. Appealing to investors (by emphasizing the for-profit nature of initiative) and potential clients (by emphasizing the social benefits), they were able to develop a new hybrid organizational form that dealt with the homeless in new, innovative ways.

\section{Relations}

Institutional entrepreneurship often involves establishing new inter-actor relations to bring about change, primarily - as much of the work discussed above indicates - through collective action (Garud et al., 2002; Lawrence et al., 2002; Wijen \& Ansari, 2007). Given that institutional entrepreneurship involves altering deeply embedded norms, values and practices, it is not surprising that it depends upon more than a single individual or organization. As a result, both the mobilization of material resources and the construction and communication of rationales for change serve to develop new relations among actors, such as collaborations, coalitions, and alliances (e.g., Buhr, 2012).

Institutional entrepreneurship is, then, associated with various forms of collaborative relations - partnerships, coalitions, etc. - that require the cooperation of other actors. It requires "the assent or, minimally, the acquiescence of various groups as well as the capacity to prevail over opposition" (Colomy, 1998: 278). For this reason it has been suggested that institutional entrepreneurs' unique political and social skills (Perkmann \& Spicer, 2007; Maguire, Hardy \& Lawrence, 2004) provide them with "the ability to induce cooperation among others" (Fligstein, 2001a: 112). We can, then, see a link between intervention strategies that mobilize material resources, those that communicate rationales, and the subsequent leveraging of inter-actor relations to get actors to participate in collective action (as well as the properties of 'exceptional' 
individuals). In this way, institutional entrepreneurship is connected to the exercise of power (Fligstein, 2001b): the overt mobilization of material resources, such as offering financial incentives, imposing penalties, or invoking formal authority, can help to coerce other field members into supporting change; while more unobtrusive harnessing of symbolic resources, in the form of discursive interventions to construct and communicate convincing rationales that legitimize new practices, can help to engender voluntary support for change. In this way, institutional entrepreneurs leverage dependencies and formal authority to change behaviors (Nasra \& Dacin, 2010), use stories and narrative accounts to induce cooperation (Fligstein, 2001b; Zilber, 2007; Hardy \& Maguire, 2010), and rely on framing to enroll allies and to build coalitions (Rao et al., 2000).

Institutional entrepreneurship can be therefore seen as the realignment - and stabilization - of material, discursive and relational arrangements in an institutional field (Levy \& Scully, 2007), with significant overlap among the three categories of intervention strategy discussed here. However, because of a bias towards studying successful instances of institutional entrepreneurship and the interest in the 'heroic' entrepreneur; other actors, especially noncooperative actors, are frequently ignored. As a result, field members that resist these intervention strategies do not figure as prominently in analyses as one might expect. We will expand upon this observation in the next section.

\section{Insights}

Most studies have found that, despite the paradox of embedded agency, institutional entrepreneurs are highly influential in shaping and changing their institutional fields; and research on 'institutional entrepreneurship' is now an established body of work within institutional theory - one that seeks to understand change in fields. Battilana, Leca \& 
Boxembaum (2009: 67) argue the "concept of institutional entrepreneurship should be central to future developments of institutional theory because it enables us to explore actors' degrees of agency, however institutionally embedded"

Empirical work shows that institutional entrepreneurship has resulted in new formal regulatory institutions at national, international and global levels of analysis, including national regulations governing industrial wastes (Demil \& Bensédrine, 2005), the reconstitution of the European Union (Fligstein, 2001a), the Stockholm Convention on Persistent Organic Pollutants (Maguire \& Hardy, 2006), and the inclusion of aviation in the EU Emissions Trading Scheme (Buhr, 2012). Institutional entrepreneurs have also helped to create new industries (Aldrich \& Fiol, 1994), such as socially responsible investment (Dejean et al., 2004), whale-watching (Lawrence \& Phillips, 2004), management consulting (David et al., 2013), recycling (Lounsbury, Ventresca \& Hirsch, 2003) and power production (Hargadon \& Douglas, 2001; Russo 2001). New organizational forms, such as the multidivisional organizational form in publishing (Thornton, 2002) and social enterprise hybrids (Tracey, Phillips \& Jarvis, 2011) have also emerged as a result of institutional entrepreneurship activities. Institutional entrepreneurs have also been responsible for the adoption of new practices, ranging from the introduction of business plans in museums (Oakes, Townley \& Cooper, 1998), new forms of diversity management (Boxenbaum \& Battilana, 2005), new ways of dealing with heart disease (Ritvala \& Granqvist, 2009), new exchange media in radio broadcasting (Leblebici et al, 1991), changes in welfare provision (Covaleski et al., 2013), and new technological standards (Garud et al., 2002). In the empirical literature, there are some, but far fewer, cases of failure to change institutions or of institutional maintenance through institutional entrepreneurship (e.g., Greenwood et al., 2002; Greenwood \& Suddaby, 2006; McGaughey, 2013; Schüssler, Rüling \& Wittneben, 2014), 
although some researchers have examined institutional maintenance (e.g., Heaphy, 2013; Micelotta \& Washington, 2013).

In reviewing this literature, we can see evidence of two different narratives of institutional entrepreneurship - one that is more actor-centric and focuses on the deliberate strategies of particular institutional entrepreneurs and another that is more process-centric and emphasizes the struggles associated with institutional entrepreneurship activities. Research that focuses on the properties of particular actors that distinguish them as institutional entrepreneurs appears more likely to produce actor-centric accounts because of its cognitive, individualistic orientation. So, too, does the work exploring how individuals and organizations occupying central, dominant positions bring about institutional change. Even the work on peripheral institutional entrepreneurs often glorifies them as a result of the focus on success under conditions of adversity. Research on institutional entrepreneurship as a form of problem-solving or uncertainty reduction project, also tends to promote the view of a (rational) independent, omnipotent actor. The work on contradictions and tensions - even though socially constructionist - can also be actor-centric through the way it attributes the ability to make sense of contradictions to specific actors, as well as the way it often treats the state of the field and contradictions themselves as objective and unproblematic.

Such actor-centric accounts tend to be functionalist, painting a neat picture of relatively rational, linear, win-win problem-solving activity. The (usually successful) institutional entrepreneur possesses a degree of reflexivity or insight that allows them to identify opportunities for change as a result of some stimuli, such as uncertainty or contradictions, or to address a recognized problem in the field. Then, using their superior political and social skills, the institutional entrepreneur intervenes strategically to realize institutional change by combining 
and mobilizing resources, rationales and relations in creative ways. Other actors play minor, supporting - and usually cooperative - roles if they figure at all, while conflict and struggle is pushed to the background.

Process-centric accounts focus on institutional entrepreneurship as an emergent outcome of activities of diverse, spatially dispersed actors, who face considerable difficulty in achieving effective collective action, and where gains for one group may imply significant losses for others. Process-centred accounts appear more likely to pay attention to other members of the field who may engage in some form of counter-framing, produce counter-narratives, or make discursive counter-moves. The outcomes that follow from institutional entrepreneurship tend to be more varied, including failure and inertia - perhaps because the struggle is self-defeating or because the prevailing discourses are too constraining. For example, Schüssler, Rüling and Wittneben's (2014) study of two decades of United Nations' climate change negotiations shows that what was hoped to be a catalyst of institutional change morphed into a mechanism of field maintenance.

Whether the focus is on the actor or the process, it is important to note that both types of account are constructions of the researcher. The way in which a researcher conducts his or her research has significant implications for the nature of their 'findings' - empirical design and theoretical conceptualization are never 'neutral'. For example, Wright and Zammuto (2013a, 2013b) produce both actor-centric and process-centric accounts of changes in the sport of English county cricket between 1943 and 1962. In one paper (2013a: 51), they examine how actors "use their field positions to create opportunities for institutional entrepreneurship". They focus on one particular individual - Colonel Rait-Kerr, who is named over fifty times in the paper - and his role in several key governance committees. Although the Colonel died before the 
change was finally implemented, we are left in no doubt as to his role as an institutional entrepreneur who brought about a new format for playing cricket.

The success of [the change] ... after several decades of field opposition to its introduction ... suggests that actors were sufficiently mobilized after Colonel Rait-Kerr's death to collaboratively complete his institutional entrepreneurship project (p. 62).

In another paper, Wright \& Zammuto (2013b) provide a more process-centred account of institutional entrepreneurship. The period featured in the earlier paper is extended both backwards and forwards to provide a longer time frame. The Colonel is not mentioned at all. Instead, the authors focus on organizational actors, which are classified as 'central elites', 'peripheral elites' and 'marginal players' and among whom there was considerable struggle. Rather than rest on the actions of an individual, this process-centric account argues that institutional change depended upon more complex alignments across societal, field and organizational levels.

There is then a choice as to whether researchers wish to focus on the actor or the process. Early research appeared to emphasize the former (Hardy \& Maguire, 2008). More recently, as more qualitative research has been brought to bear on institutional entrepreneurship, the number of process-centric accounts has increased. They contain rich descriptions of complexity and struggle, which some actors have been able to navigate. Somewhat ironically, the richness of this research, while providing greater insight into the processual complexities of institutional entrepreneurship and change, has indirectly focused even more attention on particular individuals and organizations that have been 'successful' in escaping the way in which their "intentions, 
actions, and rationality are conditioned by the institutions they wish to change" (Clegg, 2010: $10)$.

In doing so, much of the research on institutional entrepreneurship ignores the power relations that pervade institutional fields (Munir, 2015; Willmott 2015); and fails to reflect critically on the outcomes of institutional entrepreneurship, with resulting changes to the field assumed to be an improvement on the earlier situation. The notion of 'better' institutional arrangements is rarely problematized and the question of who benefits from - and who is disadvantaged by - institutional entrepreneurship is seldom addressed in these accounts (for exceptions see Khan, Munir \& Willmott 2007; Levy \& Scully, 2007; Martí \& Fernández, 2013). Studies rarely focus on how changes to the field can serve the interests of dominant actors who may adopt new practices but typically retain their dominance. In fact, regardless of whether they or other actors initiate institutional change, the reason why they change their practices is often to ensure that they remain dominant (e.g., Kodeih \& Greenwood, 2014). Institutional change projects are therefore much more likely to be 'elaborative' than 'reconstructive' (Colomy, 1998). Even when other actors engage in institutional entrepreneurship, new institutional arrangements typically emerge from "hegemonic accommodation", with dominant actors willing to cede only limited ground (Levy \& Scully, 2007).

There is, then, scope for a far more critical appreciation of institutional entrepreneurship. For example, Suddaby (2015: 93) suggests that researchers should "resist the temptation of adopting the viewpoint of managerial or shareholder elites". A second approach would be to assess critically the outcomes of institutional entrepreneurship. Another complementary approach might be to take the viewpoints of actors other than institutional entrepreneurs more seriously. In many cases, members of the field other than the champions of the institutional 
change project are simply ignored. Even when they are not ignored, they tend to be positioned at the passive end of a unilateral relationship where the institutional entrepreneur persuades them (Dew, 2006; Garud et al., 2002), reorganizes their preferences (Fligstein, 2001a), and aligns (Demil \& Benesdrine, 2005) or aggregates (Fligstein, 1997) their interests in relation to the institutionalization project. Focusing on those who occupy different positions in the field and are disadvantaged by current and future practices and who resist change (or fail to do so) offers a way to look at institutional entrepreneurship from a different vantage point.

Such approaches may go some way to putting power relations on the research agenda but, even so, the "conception of competent agency" remains paramount, privileging and naturalizing "the exercise of conscious, sovereign calculation to achieve desired ends with appropriate means" (Cooper, Ezzamel and Wilmott, 2008: 675). To redress this problem, Willmott (2011: 67) calls for a more radical solution - a "critically reflexive appreciation of the 'individual' as an institution" by revising our understanding of human agency and power. One way to do this is through the incorporation of Foucauldian conceptions of power (Clegg, 2010). While Foucault's work (e.g., Foucault, 1979; 1980) has greatly enhanced other areas of organization and management theory, institutional theory remains largely immune to it. Very few studies use a Foucauldian framework to explore institutional entrepreneurship and change (for exceptions see Maguire \& Hardy, 2009; Creed et al., 2014). This is, perhaps, surprising since, two decades ago, Clegg and Hardy (1996) pointed to clear parallels between Foucault's understanding of power and the constraining, inescapable effects of institutionalization; while, more recently, others have noted the relevance of discipline and governmentality to institutional theory (Sauder, \& Espeland, 2009; Creed et al., 2014; Vallentin, 2015). Given rising inequality and continuing environmental degradation associated with contemporary capitalism, future research on 
institutional entrepreneurship that is willing to interrogate concepts of agency and power could yield insights that are both theoretically and practically relevant.

We conclude this chapter by acknowledging that, while the interest in institutional entrepreneurship is a response to a desire to put agency back into institutional analyses of organizations, there remains a risk of the pendulum swinging too far in the other direction “celebrating heroic 'entrepreneurs' and great 'leaders' who bring about change intentionally, strategically and creatively" - and reifying fields, actors and the process of change itself (Hardy \& Maguire, 2008: 213). In 2008, we called for more process-centric accounts to mitigate this threat, arguing that we needed "research that interrogates critically and in more depth the phenomena that interest us, and we believe the way to do so is to keep matters of power and process open when studying institutional change." It appears that researchers have delivered on process but, less so, on power. 


\section{References}

Aldrich, H. E. 2012. The emergence of entrepreneurship as an academic field: A personal essay on institutional entrepreneurship. Research Policy, 41(7): 1240-1248.

Aldrich, H. E. \& Fiol, M. 1994. Fools rush in? The institutional context of industry creation. Academy of Management Review, 19(4): 645-670.

Ansari, S. \& Phillips, N. 2011. Text me! New consumer practices and change in organizational fields. Organization Science, 22(6): 1579-1599.

Archer, M. 2003. Structure, agency and the internal conversation. Cambridge: Cambridge University Press.

Avetisyan, E. \& Ferrary, M. 2013. Dynamics of stakeholders' implications in the institutionalization of the CSR field in France and in the United States. Journal of Business Ethics, 115(1): 115-133.

Battilana, J. 2006. Agency and institutions: The enabling role of Individuals' social position. Organization, 13(5): 653-676.

Battilana, J., Leca, B. \& Boxenbaum, E. 2009. How actors change institutions: towards a theory of institutional entrepreneurship. The Academy of Management Annals, 3(1): 65-107.

Beckert, J. 1999. Agency, Entrepreneurs, and institutional change. The roles of strategic choice and institutionalized practices in organizations. Organization Studies, 20(5): 777-799.

Bourdieu, P. 1986. The forms of capital. In Handbook of theory and research for the sociology of education, J. G. Richardson (ed.) New York: Greenwood Press, pp. 241-258.

Bourdieu, P. 1990. The logic of practice (R. Nice, Trans.), Cambridge: Polity.

Bourdieu, P. \& Wacquant, L. J. D. 1992. An invitation to reflexive sociology. Chicago: University of Chicago Press.

Boxenbaum, E. \& Battilana, J. 2005. Importation as innovation: transposing managerial practices across fields, Strategic Organization, 3(4): 355-383.

Buhr, K. 2012. The inclusion of aviation in the EU emissions trading scheme: Temporal conditions for institutional entrepreneurship. Organization Studies, 33(11): 1565-1587.

Carson, R. 1962. Silent spring. New York, NY: Houghton Mifflin.

Child, J., Lu, Y.\& Tsai, T. 2007. Institutional Entrepreneurship in building an Environmental Protection System for the People's Republic of China. Organization Studies, 28(7): 1013-1014. 
Clegg, S. 2010. The state, power, and agency: missing in action in institutional theory? Journal of Management Inquiry, 19(1), 4-13.

Clegg, S.R. \& Hardy, C. 1996. Representations. In Handbook of organization studies, S.R. Clegg, C. Hardy, \& W.R. Nord (eds.), London: Sage, pp. 676-708.

Clemens, E.S. \& Cook, J.M. 1999. Politics and institutionalism: Explaining durability and change, Annual Review of Sociology, 25(1): 441.

Coase, R. 1937. The nature of the firm. Economica, 16(4): 386-405.

Colomy, P. 1998. Neofunctionalism and neoinstitutionalism: Human agency and interest in institutional change. Sociological Forum, 13(2): 265-300.

Cooper, D. J., Ezzamel, M. \& Willmott, H. 2008. Examining "institutionalization": A critical theoretic perspective. In The Sage handbook of organizational institutionalism, R. Greenwood, C. Oliver, K. Sahlin-Andersson \& R. Suddaby (eds.) London: Sage, pp. 673701.

Covaleski, M. A., Dirsmith, M. W., \& Weiss, J. M. 2013. The social construction, challenge and transformation of a budgetary regime: The endogenization of welfare regulation by institutional entrepreneurs. Accounting, Organizations and Society, 38(5): 333-364.

Creed, W. D., DeJordy, R. \& Lok, J. 2010. Being the change: Resolving institutional contradiction through identity work. Academy of Management Journal, 53(6): 13361364.

Creed, W.D., Scully, M.A. \& Austin, J.A. 2002. Clothes make the person? The tailoring of legitimating accounts and the social construction of identity. Organization Science, 13(5): 475-496.

Creed, W. D., Hudson, B. A., Okhuysen, G. A. \& Smith-Crowe, K. 2014. Swimming in a sea of shame: incorporating emotion into explanations of institutional reproduction and change. Academy of Management Review, 39(3): 275-301.

David, R. J., Sine, W. D. \& Haveman, H. A. 2013. Seizing opportunity in emerging fields: How institutional entrepreneurs legitimated the professional form of management consulting. Organization Science, 24(2): 356-377.

Davis, G. F., Diekmann, K. A. \& Tinsley, C. H. 1994. The decline and fall of the conglomerate firm in the 1980s: The deinstitutionalization of an organizational form. American Sociological Review, 59(4): 547-570.

Déjean, F., Gond, J.P. \& Leca, B. 2004. Measuring the unmeasured: An institutional entrepreneur strategy in an emerging industry. Human Relations, 57(6): 741-764. 
Demil, B. \& Bensédrine, J. 2005. Processes of legitimization and pressure toward regulation. International Studies of Management and Organization, 35(2): 56-77.

Dew, N. 2006. Institutional entrepreneurship: A Coasian perspective. International Journal of Entrepreneurship and Innovation, 7(1): 13-22.

DiMaggio, P. 1988. Interest and agency in institutional theory. In Institutional patterns and culture, L. Zucker (ed.) Cambridge, MA: Ballinger Publishing Company, pp. 3-22.

DiMaggio, P. J. \& Powell, W. W. (Eds.). 1991. The new institutionalism in organizational analysis (Vol. 17). Chicago, IL: University of Chicago Press.

Dorado, S. 2005. Institutional entrepreneurship, partaking, and convening. Organization Studies, 26(3): 385-414.

Dorado, S. 2014. Microfinance re-imagined: personal banking for the poor. In The Routledge companion to entrepreneurship, T. Baker \& F. Welter (eds.) London: Routledge.

Dorado, S. \& Ventresca, M. J. 2013. Crescive entrepreneurship in complex social problems: Institutional conditions for entrepreneurial engagement. Journal of Business Venturing, 28(1): 69-82.

Durand, R. \& McGuire, J. 2005. Legitimating agencies in the face of selection: The Case of AACSB. Organization Studies, 26(2): 165-196.

Everett, J. 2002. Organizational research and the praxeology of Pierre Bourdieau. Organizational Research Methods, 5(1): 56-80.

Fligstein, N. 1991. The structural transformation of American industry: an institutional account of the causes of diversification in the largest firms, 1919-1979. In The new institutionalism in organizational analysis. W.W. Powell \& P. DiMaggio (eds.) Chicago and London: University of Chicago Press, pp. 311-336.

Fligstein, N. 1997. Social skill and institutional theory. American Behavioral Scientist, 40(4): 397-405.

Fligstein, N. 2001a. Institutional entrepreneurs and cultural frames - The case of the European Union's single market program. European Societies, 3(3): 261-287.

Fligstein, N. 2001b. Social skill and the theory of fields. Sociological Theory, 19(2): 105-125.

Fligstein, N. \& Mara-Drita, I. 1996. How to make a market: reflections on the attempt to create a single market in the European Union. American journal of Sociology, 102(1): 1-33.

Foucault, M. (1979). Discipline and punish: The birth of the prison. Harmondsworth: Penguin. 
Foucault, M. (1980). Power/Knowledge: Selected interviews and other writings 1972-1977, C. Gordon, (ed.) Brighton: Harvester Press.

Garud, R., Hardy, C. \& Maguire, S. 2007. Institutional entrepreneurship as embedded agency: An introduction to the special issue. Organization Studies, 28(7): 957-969.

Garud, R., Jain, S. \& Kumaraswamy, A. 2002. Institutional entrepreneurship in the sponsorship of common technological standards: The case of Sun Microsystems and Java. Academy of Management Journal, 45(1): 196-214.

George, E., Chattopadhyay, P. Sitkin, S.B. \& Barden, J.2006. Cognitive underpinning of institutional persistence and change: A framing perspective. Academy of Management Review, 31(2): 347-385.

Grant, D. \& Hardy, C. 2004. Struggles with organizational discourse. Organization Studies, 25(1): 5-14.

Gray, B., Purkey, J.M. \& Ansari, S. 2015. From interactions to institutions: Microprocesses of framing and mechanisms for the structuring of institutional fields. Academy of Management Review, 40(1): 115-143.

Greenwood, R. \& Suddaby, R. 2006. Institutional Entrepreneurship in mature fields: The big five accounting firms. Academy of Management Journal, 49(1): 27-48.

Greenwood, R., Suddaby, R. \& Hinings, C.R. 2002. Theorizing Change: The Role of Professional Associations in the Transformations of Institutionalized Fields. Academy of Management Journal, 45(1): 58-80.

Hardy, C. \& Maguire, S. 2008. Institutional entrepreneurship. The Sage handbook of organizational institutionalism, R. Greenwood, C. Oliver, K. Sahlin-Andersson \& R. Suddaby (eds.) London: Sage, pp. 198-217.

Hardy, C. \& Maguire, S. 2010. Discourse, field-configuring events, and change in organizations and institutional fields: Narratives of DDT and the Stockholm Convention. Academy of Management Journal, 53(6), 1365-1392.

Hardy, C. \& Philips, N. 1999. No joking matter: Discursive struggle in the Canadian refugee system. Organization Studies, 20(1): 1-24.

Hargadon, A. \& Douglas, Y. 2001. When innovations meet institutions: Edison and the design of the electric light. Administrative Science Quarterly, 46(3): 476-501.

Harmon, D. J., Green, S. E. \& Goodnight, G. T. 2015. A model of rhetorical legitimation: The structure of communication and cognition underlying institutional maintenance and change. Academy of Management Review, 40(1), 76-95. 
Heaphy, E. D., 2013, Repairing breaches with rules: Maintaining institutions in the face of everyday disruptions, Organization Science, 24(5): 1291-1315.

Henfridsson, O., Yoo, Y. 2014. The liminality of trajectory shifts in institutional entrepreneurship. Organization Science, 25(3): 932-950.

Hensman, M. 2003. Social movement organizations: A metaphor for strategic actors in institutional field. Organization Studies, 24(3): 355-381.

Hoffman, A.J. 1999. Institutional evolution and change: Environmentalism and the U.S. chemical industry. Academy of Management Journal, 42(4): 351-371.

Holm, P. 1995. The dynamics of institutionalisation: Transformation processes in Norwegian fisheries. Administrative Science Quarterly, 40(3): 398-422.

Khan, F., Munir, K. \& Willmott, H. 2007. A dark side of institutional entrepreneurship: Soccer balls, child labor and postcolonial impoverishment. Organization Studies, 28(7): 10551077.

Kodeih, F. \& Greenwood, R. 2014. Responding to institutional complexity: The role of identity. Organization Studies, 35(1): 7-39.

Kisfalvi, V. \& Maguire, S. 2011. On the nature of institutional entrepreneurs: Insights from the life of Rachel Carson. Journal of Management Inquiry, 20(2): 152-177.

Lampel, J. \& Meyer, A. D. 2008. Guest editors' introduction: Field-configuring events as structuring mechanisms: How conferences, ceremonies, and trade shows constitute new technologies, industries, and markets. Journal of Management Studies, 45(6): 10251035.

Lawrence, T., Hardy, C. \& Phillips, N. 2002. Institutional effects of interorganizational collaboration: The emergence of proto-institutions. Academy of Management Journal, 45(1): 281-290.

Lawrence, T. \& Phillips, N. 2004. From Moby Dick to Free Willy: macro-cultural discourse and institutional entrepreneurship in emerging institutional fields. Organization, 11(5): 689711.

Lawrence, T. \& Suddaby, R. 2006. Institutions and institutional work. In Handbook of organization studies, S.R. Clegg, C. Hardy, T.B. Lawrence \& W.R. Nord (eds.) London: Sage, pp. 215-254.

Leblebici, H., Salancik, G., Copay, A. \& King, T. 1991. Institutional change and the transformation of interorganizational fields: An organizational history of the U.S. radio broadcasting industry. Administrative Science Quarterly, 36(3): 333-363. 
Leca, B. \& Naccache, P. 2006. A critical realist approach to institutional entrepreneurship. Organization, 13(5): 627-651.

Lee, K. \& Pennings, J.M. 2002. Mimicry and the market: Adoption of a new organizational form. Academy of Management Journal, 45(1): 144-162.

Lepoutre, J. M. \& Valente, M. 2012. Fools breaking out: The role of symbolic and material immunity in explaining institutional nonconformity. Academy of Management Journal, 55(2): 285-313.

Levy, D. \& Scully, M. 2007. The institutional entrepreneur as modern prince: The strategic face of power in contested fields. Organization Studies, 28(7): 971-991.

Lounsbury, M. 2002. Institutional transformation and status mobility: the professionalization of the field of finance. Academy of Management Journal, 45(1): 255-266.

Lounsbury, M., Ventresca, M. \& Hirsch, P.M. 2003. Social movements, field frames and industry emergence: a cultural-political perspective on US recycling. Social Economic Review, 1(1): 71-104.

Maguire, S. 2007. Institutional entrepreneurship. In International encyclopedia of organization studies, S. Clegg, and J.R Bailey, (eds.) London, UK: Sage, pp. 674-678.

Maguire, S. \& Hardy, C. 2006. The emergence of new global institutions: A discursive perspective. Organization Studies, 27(1): 7-29.

Maguire, S. \& Hardy, C. 2009. Discourse and deinstitutionalization: The decline of DDT. Academy of Management Journal, 52(1): 148-178.

Maguire, S., Hardy, C. \& Lawrence, T. 2004. Institutional entrepreneurship in emerging fields: HIV/AIDS treatment advocacy in Canada. Academy of Management Journal, 47(5): 657-679.

Maguire, S., Phillips, N. \& Hardy, C. 2001. "When 'Silence = Death', keep talking: Trust, control and the discursive construction of identity in the Canadian HIV/AIDS treatment domain". Organization Studies, 22(2): 285-312.

Martí, I. \& Fernández, P. 2013. The Institutional work of oppression and resistance: Learning from the Holocaust. Organization Studies, 34(8): 1195-1223.

McGaughey, S. L. 2013. Institutional entrepreneurship in North American lightning protection standards: Rhetorical history and unintended consequences of failure. Business History, 55(1): 73-97.

Meyer, A.D. 1982. Adapting to environmental jolts. Administrative Science Quarterly, 27(4): 515-537. 
Meyer, R.E. 2006. Visiting relatives: Current developments in the new sociology of knowledge. Organization, 13(5): 725-738.

Micelotta, E.\& Washington, M. 2013. Institutions and maintenance: the repair work of Italian professions. Organization Studies, 34(8): 1137-1170.

Misangyi, V. F., Weaver, G. R. \& Elms, H. 2008. Ending corruption: The interplay among institutional logics, resources, and institutional entrepreneurs. Academy of Management Review, 33(3): 750-770.

Montiel, I. \& Husted, B. W. 2009. The adoption of voluntary environmental management programs in Mexico: First movers as institutional entrepreneurs. Journal of Business Ethics, 88(2): 349-363.

Monteiro, P. \& Nicolini, D. 2014. Recovering materiality in institutional work prizes as an assemblage of human and material entities. Journal of Management Inquiry, 24(1): 6181 .

Munir, K.A. 2005. The social construction of events: A study of institutional change in the photographic field. Organization Studies, 26(1): 93-112.

Munir, K.A. 2015. A loss of power in institutional theory. Journal of Management Inquiry, 24(1): 90-92.

Mutch, A. 2007. Reflexivity and the institutional entrepreneur: a historical exploration.

Organization Studies, 28(7): 1123-1140.

Mutch, A., Delbridge, R. \& Ventresca, M. 2006. Situating organizational action: The relational sociology of organizations. Organization, 13(5): 607-625.

Nasra, R. \& Dacin, M. T. 2010. Institutional arrangements and international entrepreneurship: the state as institutional entrepreneur. Entrepreneurship Theory and Practice, 34(3): 583-609.

North, D.C. 1990. Institutions, institutional change and economic performance. Cambridge: Cambridge University Press.

Oakes, L.S., Townley, B. \& Cooper, D.J. 1998. Business planning as pedagogy: Language and control in a changing institutional field. Administrative Science Quarterly, 43(2): 257292.

Perkmann, M. \& Spicer, A. 2007. Healing the scars of history: Projects, skills and field strategies in institutional entrepreneurship. Organization Studies, 28(7): 1101-1122. 
Pfeffer, J. \& Salancik, G. 1978. The external control of organizations. New York: Harper and Row.

Phillips, N., Lawrence, T. \& Hardy, C. 2004. Discourse and institutions. Academy of Management Review, 29(4): 1-18.

Purdy, J. M. \& Gray, B. 2009. Conflicting logics, mechanisms of diffusion, and multilevel dynamics in emerging institutional fields. Academy of Management Journal, 52(2): 355380 .

Raffaelli, R. \& Glynn, M. A. 2014. Turnkey or tailored? Relational pluralism, institutional complexity, and the organizational adoption of more or less customized practices. Academy of Management Journal, 57(2): 541-562.

Rao, H. 2002. Tests tell: Institutional activists, constitutive legitimacy and consumer acceptance in the American automobile industry, 1895-1912. Advances in Strategic Management the New Institutionalism in Strategic Management, 19: 307-335.

Rao, H., Monin, P. \& Durand, R. 2003. Institutional change in Toque Ville: Nouvelle cuisine as an identity movement in French gastronomy. American Journal of Sociology, 108(4): 795-843.

Rao, H., Morrill, C. \& Zald, M. 2000. Power plays: How social movements and collective action create new organizational forms. Research in Organizational Behavior, 22: 237-281.

Ritvala, T. \& Granqvist, N. 2009. Institutional entrepreneurs and local embedding of global scientific ideas-The case of preventing heart disease in Finland. Scandinavian Journal of Management, 25(2): 133-145.

Rothenberg, S. \& Levy, D. L. 2012. Corporate perceptions of climate science: The role of corporate environmental scientists. Business \& Society, 51(1): 31-61.

Russo, M.V. 2001. Institutions, exchange relations, and the emergence of new fields: Regulatory policies and independent power production in America, 1978-1992. Administrative Science Quarterly, 46(1): 57-86.

Sahlin, K. \& Wedlin, 2008. Circulating ideas: Imitation, translation and editing. In The Sage handbook of organizational institutionalism, R. Greenwood, C. Oliver, K. SahlinAndersson \& R. Suddaby (eds.), London: Sage, pp. 218-242.

Sauder, M. 2008. Interlopers and field change: the entry of US News into the Field of Legal education. Administrative Science Quarterly, 53(2): 209-234.

Sauder, M. \& Espeland, W. N. 2009. The discipline of rankings: Tight coupling and organizational change. American Sociological Review, 74(1): 63-82. 
Schmidt, V. A. 2008. Discursive institutionalism: The explanatory power of ideas and discourse. Annual Review of Political Science, 11: 303-326.

Schmidt, V. A. 2010. Taking ideas and discourse seriously: explaining change through discursive institutionalism as the fourth 'new institutionalism'. European Political Science Review, 2(1): 1-25.

Schüssler, E., Rüling, C. C. \& Wittneben, B. B. 2014. On melting summits: The limitations of field-configuring events as catalysts of change in transnational climate policy. Academy of Management Journal, 57(1): 140-171.

Scott, R. 1995. Institutions and organizations. Thousand Oaks, CA: Sage.

Seo, M. \& Creed, D. 2002. Institutional contradictions, praxis and institutional change: A dialectic perspective. Academy of Management Review, 27(2): 222-248.

Sherer, P.D. \& Lee, K. 2002. Institutional change in large law firms: A resource dependency and institutional perspective. Academy of Management Journal, 45(1): 102-119.

Smets, M., Morris, T. I. M. \& Greenwood, R. 2012. From practice to field: A multilevel model of practice-driven institutional change. Academy of Management Journal, 55(4): 877904.

Stål, H. 2011. Examining the relationship between emerging and prevailing institutional logics in an early stage of institutional entrepreneurship. Journal of Change Management, 11(4): 421-443.

Suddaby, R. (2015). Can institutional theory be critical? Journal of Management Inquiry, 24(1) 93-95.

Suddaby, R. \& Greenwood, R. 2005. Rhetorical strategies of legitimacy. Administrative Science Quarterly, 50(1): 35-68.

Thornton, P.H. 2002. The rise of the corporation in a craft industry: Conflict and conformity in institutional logics. Academy of Management Journal, 45(1): 81-101.

Thornton, P. H. \& Ocasio, W. 2008. Institutional logics. In The Sage handbook of organizational institutionalism, R. Greenwood, C. Oliver, K. Sahlin-Andersson \& R. Suddaby (eds.) London: Sage, pp. 99-128.

Tracey, P., Phillips, N. \& Jarvis, O. 2011. Bridging institutional entrepreneurship and the creation of new organizational forms: A multilevel model. Organization Science, 22(1): 60-80.

Townley, B. 2002. The role of competing rationalities in institutional change. Academy of Management Journal, 45(1): 163-179. 
Turner, R. \& Killian, L. 1987. Collective behaviour. Englewood Cliffs, NJ: Prentice Hall.

Vallentin, S. 2015. Governmentalities of CSR: Danish government policy as a reflection of political difference. Journal of Business Ethics, 127(1): 33-47.

Wijen, F. \& Ansari, S. 2007. Overcoming inaction through collective institutional entrepreneurship: Insights from regime theory. Organization Studies, 28(7): 1079-1100.

Willmott, H. 2011. Institutional work: for what? Problems and prospects of institutional theory. Journal of Management Inquiry, 20(1): 67-72.

Willmott, H. 2015. Why institutional theory cannot be critical. Journal of Management Inquiry, 24(1): 105-111.

Wright, A. L. \& Zammuto, R. F. 2013a. Creating opportunities for institutional entrepreneurship: The Colonel and the Cup in English County Cricket. Journal of Business Venturing, 28(1): 51-68.

Wright, A. L. \& Zammuto, R. F. 2013b. Wielding the willow: Processes of institutional change in English county cricket. Academy of Management Journal, 56(1), 308-330.

Zilber, T.B. 2002. Institutionalization as an interplay between actions, meanings and actors: The case of a rape crisis center in Israel. Academy of Management Journal, 45(1): 234-254.

Zilber, T.B. 2006. The work of the symbolic in institutional processes: Translations of rational myths in Israeli hi-tech. Academy Management Journal, 49(2): 281-303.

Zilber, T.B. 2007. Stories and the discursive dynamics of institutional entrepreneurship: The case of Israeli high-tech after the bubble. Organization Studies, 28(7): 1035-1054. 